\title{
PENERAPAN MODEL PROBLEM BASED LEARNING BERBANTUAN MEDIA KARTU GAMBAR ILUSTRASI UNTUK MENINGKATKAN PEMAHAMAN KONSEP SISWA KELAS IV SEKOLAH DASAR
}

\author{
Virginia Annisa, Nur Fajrie, dan Muhammad Noor Ahsin
}

1,2,3 Universitas Muria Kudus

Email: Virginiavira@gmail.com

\begin{tabular}{l}
\hline Info Artikel \\
\hline Sejarah Artikel: \\
Diserahkan 01 Juli 2020 \\
Direvisi 22 Juli 2020 \\
Direvisi 29 Juli 2020 \\
Disetujui 16 Agustus 2020 \\
\hline
\end{tabular}

Keywords:

problem based learning,

concept understanding,

image card,

media ilustration

\begin{abstract}
The purpose of this study was to improve students' conceptual understanding and teacher skills by applying the Problem Based Learning learning model assisted by illustration image card media in grade IV SD N 4 Kalipucang Wetan.

The research method used is Classroom Action Research (PTK) with reference to the Kemmis and Mc. Taggart which consists of four steps, namely 1) Planning, 2) Observation, 3) Implementation, and 4) Reflection. The subjects of this study were the fourth grade students of SD N 4 Kalipucang Wetan, totaling 21 students consisting of 7 female students and 14 male students. Data collection techniques using test and non-test techniques. The test technique is carried out through a learning evaluation test which is carried out at the end of the cycle, while the non-test techniques used include: 1) observation or observation including the teacher's skill observation sheet and the observation sheet for understanding the concept of attitude and skill aspects, 2) interviews, namely structured interviews, 3) documentation. The data checking technique used is the content validity of Expert Judgment. The data analysis technique was carried out in a descriptive comparative manner.

The results showed that the use of the Problem Based Learning learning model could improve students' conceptual understanding of the knowledge aspect in the first cycle with an average score of 72.428. In the second cycle, the average score increased again by 75.285. Teacher skills in cycle I with an average score of $67 \%$ and cycle II an average score of 78\%. Based on the data above, it can be concluded that using the Problem Based Learning model assisted by illustration image card media can improve students' conceptual understanding skills and teacher skills on the theme of the Beauty of Diversity in My Country in grade IV SD N 4 Kalipucang Wetan.
\end{abstract}

\begin{abstract}
Abstrak
Tujuan penelitian ini yaitu meningkatkan pemahaman konsep siswa dan keterampilan guru dengan penerapan model pembelajaran Problem Based Learning berbantuan media kartu gambar ilustrasi di kelas IV SD N 4 Kalipucang Wetan.

Metode penelitian yang digunakan yaitu Penelitian Tindakan Kelas (PTK) dengan merujuk pada model Kemmis dan Mc. Taggart yang terdiri dari empat langkah yaitu 1) Perencanaan, 2) Pengamatan, 3) Pelaksanaan, dan 4) Refleksi. Subjek penelitian ini yaitu siswa kelas IV SD N 4 Kalipucang Wetan yang berjumlah 21 siswa yang terdiri atas 7 siswa perempuan dan 14 siswa laki-laki. Teknik pengumpulan data menggunakan teknik tes dan nontes. Teknik tes dilakukan melalui tes evaluasi belajar yang dilaksanakaan pada akhir siklus, sedangkan teknik nontes yang digunakan meliputi: 1) observasi atau pengamatan meliputi lembar observasi keterampilan guru dan lembar observasi pemahaman konsep aspek sikap dan aspek keterampilan, 2) wawancara yaitu wawancara terstuktur, 3) dokumentasi. Teknik pemeriksaan data yang digunakan yaitu validitas isi Expert Judgement. Teknik analisis data dilakukan secara deskriptif komparatif.

Hasil penelitian menunjukkan bahwa penggunaan model pembelajaran Problem Based Learning dapat meningkatkan pemahaman konsep siswa pada aspek pengetahuan pada siklus I skor rata-rata sebesar 72,428. Pada siklus II mengalami peningkatan lagi skor ratarata sebesar 75,285. Keterampilan guru pada siklus I dengan skor rata-rata sebesar $67 \%$ dan siklus II skor rata-rata sebesar $78 \%$. Berdarkan data di atas maka dapat disimpulkan bahwa dengan menggunakan model Problem Based Learning berbantuan media kartu gambar ilustrasi dapat meningkat kemampuan pemahaman konsep siswa dan keterampilan guru tema Indahnya Keragaman di Negeriku di kelas IV SD N 4 Kalipucang Wetan.
\end{abstract}

(C2021 Universitas Muria Kudus 


\section{PENDAHULUAN}

Kemampuan pemahaman konsep siswa di SD N 4 Kalipucang Wetan masih rendah. Hal tersebut dibuktikan dengan kesulitan dalam dalam memahami materi terutama pada muatan Ilmu Pengetahuan Sosial (IPS) yang mengajak siswa untuk menghafal. Berdasarkan hasil wawancara dengan Sutomo, S.Pd. SD., selaku guru kelas IV dan observasi pada tanggal 30 November 2019 diketahui bahwa terdapat kelemahan yang mengarah pada tingkat rendahnya pemahaman konsep siswa. Selanjutnya dari hasil uji pra siklus diperoleh skor rata-rata sebesar 73,190 dengan persentase sebesar $47,61 \%$. Sedangkan persentase siswa yang belum mencapai ketuntasan sebesar 52,39\% yang artinya hasil belajar siswa kelas IV SD N 4 Kalipucang Wetan masih rendah.

Observasi yang dilakukan di kelas IV tema 7 Indahnya Keragaman di Negeriku yang berfokus pada pada muatan IPS terdapat beberapa temuan meliputi 1) belum digunakannya media pada setiap pembelajaran, 2) guru hanya terpaku pada buku pegangan saja. Dengan adanya permasalahan tersebut guru kelas IV SD dapat meningkatkan kemampuan pemahaman konsep siswa melalui pembelajaran kreatif dan menyenangkan.

Tugas pendidik atau guru adalah menciptakan suasana pembelajaran yang dapat menciptakan suasana pembelajaran yang dapat menyenangkan dan siswa dapat memahami materi yang diberikan guru dalam belajar. Suasana pembelajaran yang demikian akan berdampak positif dalam pencapaian tujuan pembelajaran yang optimal.

Berdasarkan kondisi tersebut maka guru harus mencari strategi, metode, dan model pembelajaran yang dapat meningkatkan kemampuan pemahaman konsep siswa. Hal tersebut guru harus menekankan keseimbangan proses pembelajaran dengan model pembelajaran Problem Based Learning untuk memberikan peluang kepada siswa mencari suatu masalah.

Model pembelajaran Problem Based Learning merupakan model pembelajaran yang membutukkan penyelidikan autetik (penyelidikan yang membutuhkan penyelesaian nyata dari contoh permasalahan nyata) dalam suatu permasalahan. Contoh nyata membantu siswa memahami konsep bukan sekedar teori saja (Ardianti dkk, 2019). Penyelidikan juga membuat siswa mengetahui konsep dan dapat melatih daya nalar berpikir kritis dengan cara memproses informasi yang sudah jadi dalam benaknya dan menyusun mereka sendiri tentang dunia dan sekitarnya (Rahmanto dan Suprayitno, 2018).

Hal tersebut senada dengan pendapat Siregar dalam Mintarsih (2017) berpendapat bahwa model Problem Based Learning merupakan model pembelajaran yang berfokus pada penyajian suatu permasalahan (nyata dan stimulasi) kepada siswa, kemudian siswa diminta mencari pemecahannya melalui serangkaian penelitian atau investigasi berdasarkan teori, konsep, prinsip yang dipelajarinya dari berbagai bidang ilmu. Kusumawati (2015) menyebut pembelajaran berbasis masalah (problem based learning) adalah suatu proses belajar mengajar di dalam kelas dimana siswa terlebih dahulu diminta mengobservasi suatu fenomena. Kemudian siswa diminta untuk mencatat permasalahan-permasalahan yang muncul, setelah itu tugas guru adalah merangsang untuk berpikir kritis dalam memecahkan masalah yang ada.Tugas guru mengarahkan untuk bertanya, membuktikan, asumsi, dan mendengarkan persfektif yang berbeda diantara mereka.

Susanti (2018) menyatakan model pembelajaran berbasis masalah (problem based learning) adalah rangkaian aktivitas pembelajaran yang memuat fase-fase kegiatan pembelajaran yang dikembangkan menggunakan masalah autentik, memfasilitasi, penyelidikan, siswa aktif berpikir, berkomunikasi, mencari, mengolah data dan akhirnya menyimpulkan serta mengarahkan siswa pada kemampuan pemecahan masalah. Berdasarkan pendapat di atas maka peneliti dapat menyimpulkan bahwa model Problem Based Learning adalah model pembelajaran yang dapat menciptakan siswa memahami materi lewat penemuan-penemuan atau berpedoman dengan masalah sehingga siswa dihadapkan pada suatu masalah untuk di selesaikan selama proses pembelajaran berlangsung. Pemilihan model Problem Based Learning (PBL) pada riset ini senada dengan penelitian Zuliana (2015); riset Santoso dan Oktavianti (2015); serta penelitian Malinda, Murtono, dan Zuliana (2017).

Langkah-langkah model pembelajaran -

Problem Based Learning (PBL) peneliti beracuan pada langkah-langkah model pembelajaran oleh Sani (2015) dalam Mintarsih dan Termedi (2017) sebagai berikut: 1) Mengorientasikan siswa terdapat masalah, 2) Mengorientasikan siswa untuk belajar, 3) Membimbing penyelidikan individual maupun kelompok, 4) Mengembangkan dan menyajikan hasil karya, 5) Menganalisis dan mengevalusai proses pemecahan masalah. 
Upaya peningkatan kemampuan pemahaman konsep siswa dapat didukung dengan penggunaan media. Media juga menjadi suasana proses pembelajaran akar tidak membosankan dan membuat siswa aktif (Astuti dkk, 2020). Peneliti menggunakan media kartu gambar ilustrasi supaya siswa bisa aktif dan kelas menjadi kondusif dalam proses pembelajaran. Media kartu gambar ilustrasi adalah media yang hanya mengandalkan indera penglihatan dan dapat menjelaskan suatu kejadian atau peristiwa yang berupa foto atau gambar agar mudah dipahami. Media kartu gambar ilustrasi diciptakan peneliti untuk mengetahui apa saja keragaman yang ada di Indonesia.

Media ini berisi tentang gambar keragaman di Indonesia seperti pakaian adat, rumah adat, senjata tradisional, suku di Indonesia, macam-macam tari dan masih banyak lagi yang lainnya. Siswanya diminta untuk menganalisis atau mengevaluasi dalam suatu kelompok pada media kartu gambar ilustrasi tersebut kemidian salah satu kelompok bisa menyajikan/ mempresentasikan hasil karya tersebut di depan kelas. Pemilihan media kartu pada penelitian ini senada dengan riset Sulistyani (2020); serta penelitian Amalia, Roysa, dan Ismaya (2020).

Sani dalam Mintarsih (2017) berpendapat bahwa pemahaman konsep adalah kemampuan menangkap pengertian-pengertian seperti mampu mengungkapkan suatu materi yang disajikan ke dalam bentuk yang lebih dipahami, mampu memberikan interpretasi dan mampu mengaplikasikannya. Hal tersebut senada dengan pendapat Rosmawati (dalam putri, dkk 2012) "pemahaman konsep adalah yang berupa penguasaan materi pembelajaran, dimana siswa tidak sekedar mengenal dan mengetahui, tetapi mampu mengungkapkan kembali konsep dalam bentuk yang lebih mudah dimengerti serta mampu mengaplikasikan kembali”.

Sanjaya (Harja, 2012) menjelaskan pemahaman konsep adalah kemampuan siswa yang berupa penguasaan sejumlah materi pelajaran, dimana siswa tidak sekedar mengetahui atau mengingat sejumlah konsep yang dipelajari, tetapi mampu mengungkapkan kembali dalam bentuk lain yang mudah dimengerti, memberikan interprestasi data dan mampu mengaplikasikan konsep yang sesuai dengan struktur kognitif yang dimilikinya. Berdasarkan paparan para ahli di atas maka dapat disimpulkan bahwa pemahaman konsep adalah kompetensi yang harus dimiliki siswa untuk memahami sejumlah konsep materi yang diajarkan dan mengulang kembali ke dalam bentuk yang lebih mudah dimengerti.

Adapun indikator pemahaman konsep siswa menurut Depdiknas (2006:59) sebagai berikut: 1) Menyatakan ulang sebuah konsep. 2) Mengklasifikasi objek menuruttertentu sesuai dengan konsepnya. 3) Memberikan contoh dan bukan contoh dari suatu konsep. 4) Menyajikan konsep dalam berbagai bentuk representasi matematis. 5) Mengembangkan syarat perlu atau syarat cukup dari suatu konsep. 6) Menggunakan dan memanfaatkan serta memilih prosedur atau operasi tertentu. 7) Mengaplikasikan konsep atau logaritma dalam pemecahan masalah.

Berdasarkan uraian di atas, penelitian yang bertujuan meningkatkan pemahaman konsep siswa dengan penerapan model pembelajaran problem based learning berbantuan media kartu gambar ilustrasi kelas IV SD N 4 Kalipucang Wetan Jepara dan untuk meningkatkan keterampilan mengajar guru dengan penerapan model pembelajaran problem based learning berbantuan media kartu gambar ilustrasi kelas IV SD N 4 Kalipucang Wetan Jepara.

\section{METODE PENELITIAN}

Jenis penelitian ini yang digunakan yaitu Penelitian Tindakan Kelas (PTK) dengan merujuk pada model Kemmis dan Mc. Taggart (dalam Arikunto, 2014: 138). Adapun model PTK dimaksud adanya empat langkah yaitu 1) Perencanaan, 2) Pengamatan, 3) Pelaksanaan, dan 4) Refleksi.

Subjek penelitian ini yaitu siswa kelas IV SD N 4 Kalipucang Wetan yang berjumlah 21 siswa yang terdiri atas 7 siswa perempuan dan 14 siswa laki-laki. Lokasi penelitian di Desa Kalipucang Wetan Rt 7 Rw 3 Kecamatan Welahan Kabupaten Jepara Provinsi Jawa Tengah. Penelitian ini dilaksanakan pada semester genap tahun ajaran 2019/2020.

Teknik pengumpulan data menggunakan tes dan nontes. Teknik tes melalui tes evaluasi belajar yang dilaksanakaan pada akhir siklus. Tes yang peneliti gunakan berupa tes essay berdasarkan indikator atau kompetensi yang diharapkan dapat dicapai oleh siswa dan dilalsanakan di akhir pertemuan pada setiap siklus. Sedangkan teknik nontes yang digunakan meliputi: 1) observasi atau pengamatan observasi pemahaman konsep aspek sikap dan aspek keterampilan, 2) wawancara yaitu wawancara terstuktur, 3) dokumentasi. Teknik dan instrument penelitian disajikan dalam Tabel 1. 
Virginia Annisa, Nur Fajrie, dan Muhammad Noor Ahsin

PENERAPAN MODEL PROBLEM BASED LEARNING BERBANTUAN MEDIA KARTU ...

WASIS: Jurnal Ilmiah Pendidikan Volume 2 Nomor 1, Mei 2021, hlm. 1-8

Tabel 1 Teknik dan Intrument (alat pengumpulan data)

\begin{tabular}{lll}
\multicolumn{1}{c}{ Jenis Data } & \multicolumn{1}{c}{ Teknik } & \multicolumn{1}{c}{ Instrument } \\
\hline Hasil Belajar Kognitif & Soal & Soal \\
\hline Hasil Belajar Afektif & Observasi & Rubik Penilaian Sikap \\
\hline Hasil Belajar Psikomotorik & Observasi & Rubik Penilaian Keterampilan \\
\hline
\end{tabular}

Sumber data yang peneliti gunakan yaitu sumber data primer dan sumber data skunder. Sumber data skunder diperoleh penetiti dari siswa, dan data dokumentasi. Sumber data primer siswa diperoleh dari hasil observasi aktivitas belajar siswa, tes evaluasi belajar, dan data dokumentasi yang diperoleh selama pelaksanaan siklus I dan II.

Sumber data primer guru diperoleh dari lembar observasi keterampilan guru dalam pembelajaraan Problem Based Learning pada pembelajaran IPS. Sumber data primer dukumentasi berupa data kegiatan lembar pengamatan aktivitas belajar siswa dan keterampilan guru dalam pembelajaran dan foto dokumentasi jalannya pelaksanaan pembelajaran. Sedangkan sumber data skunder diperoleh dari referensi buku yang digunakan dalam penyusunan proposal PTK, jurnal penelitian, lembar pengamatan guru, lembar aktivitas siswa, foto, daftar siswa kelas IV dan nilai awal dari tes yang berupa nilai ulangan harian.

Teknik pemeriksaan data (mengukur keabsahan data) yang digunakan penelitian ini divalidasi oleh para ahli dengan mengisi lembar validitas isi Expert Judgement dengan memberikan skor 1-5 pada masing-masing aspek yang berhubungan dengan instrument validitas isi digunakan mengukur hasil belajar siswa.

Teknik analisis data dapat diperoleh dari data kualitatif dan kuantitatif data yang dapat dianalisis secara deskriptif. Analisis data yang digunakan dalam penelitian ini yaitu deskriptif komparatif yaitu teknik analisis data dengan membandingkan hasil antar siklus, hasil belajar siklus I dibandingkan dengan hasil belajar siklus II. Data kualitatif diperoleh dari hasil pengamatan siswa dalam mengikuti pembelajaran, sedangkan pengamatan guru dilakukan ketika guru melaksanakan pembelajaran menggunakan model Problem Based Learning berbantuan media kartu gambar ilustrasi. Data kuantitatif diperoleh dari hasil tes tertulis yang diberikan kepada siswa setiap akhir siklus I dan II.

\section{HASIL DAN PEMBAHASAN \\ HASIL}

Hasil pengamatan pada pemahaman konsep siswa aspek sikap di kelas IV SD N 4
Kalipucang Wetan pada prasiklus menunjukkan nilai rata-rata sebesar $40 \%$ dalam kriteria kurang baik. Hasil penelitian aspek keterampilan kelas IV SD N 4 Kalipucang Wetan pada prasiklus menunjukkan skor rata-rata sebesar $45 \%$ dalam kriteria kurang baik. Hasil nilai ulangan siswa kelas IV menunjukkan bahwa sebanyak 11 siswa sebesar 52,39\% tuntas dan 10 siswa sebesar $47,61 \%$ tidak tuntas.

Penelitian dilaksanakan dalam 2 siklus yang terdiri atas 2 pertemuan. Pelaksanaan siklus I pertemuan 1 dan 2 dilaksanakan pada tanggal 14 Februari 2020 dan 15 Februari 2020. Pelaksanaan siklus II pertemuan 1 dan 2 di laksanakan pada tanggal 19 Februari 2020 dan 20 Februari 2020.

\section{Keterampilan Mengajar Guru}

'Hasil pengamatan keterampilan mengajar guru pada prasiklus, siklus I dan siklus II yang dilakukan observer 1 dapat dilihat pada Tabel 2 dan Gambar 1 sebagai berikut.

Tabel 2 Peningkatan Keterampilan Guru

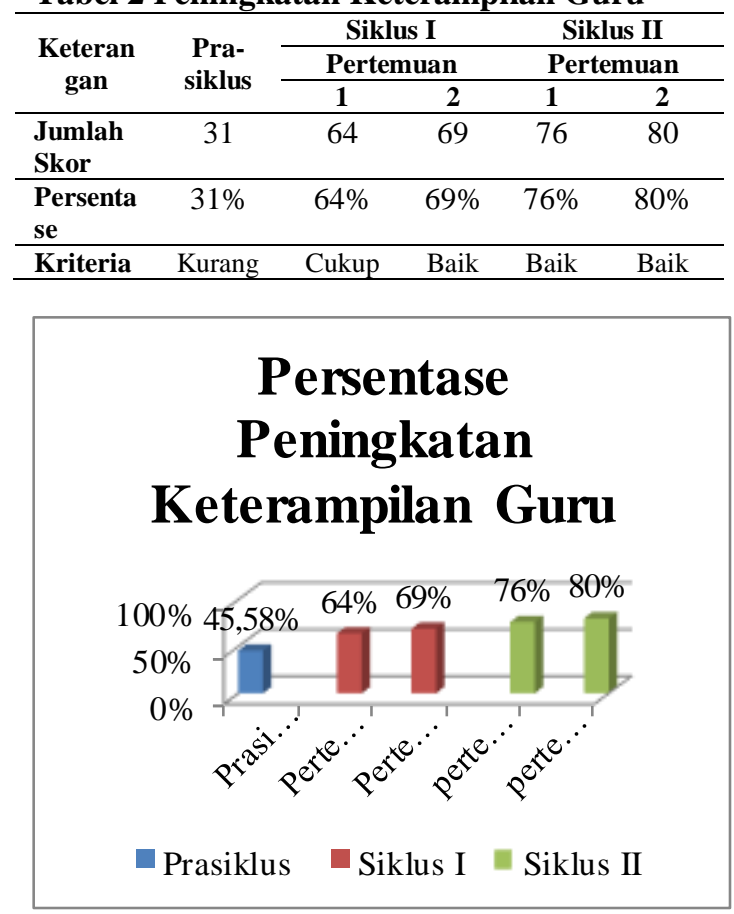

Gambar 1 Diagram Persentase peningkatan Keterampilan Guru 
Berdasarkan data tabel dan diagram hasil pengamatan diketahui bahwa keterampilan mengajar guru meningkat pada prasiklus dengan persentase sebesar 45,58\% dalam kriteria kurang. Siklus I pertemuan 1 dengan persentase sebesar $64 \%$ dalam kriteria cukup dan siklus I pertemuan 2 dengan persentase $69 \%$ dalam kriteria baik. Pada siklus I ini keterampilan guru meningkat tetapi belum memenuhi indikator tingkat keberhasilan yaitu $75 \%$. Siklus II pertemuan 1 meningkat menjadi dengan persentase sebesar $76 \%$ dalam kriteria baik dan siklus II pertemuan 2 dengan persentase sebesar $80 \%$ dalam kriteria baik. Pada siklus II ini sudah memenuhi indikator tingkat keberhasilan yaitu $75 \%$.

\section{Pemahaman Konsep Siswa}

Hasil pengamatan pemahaman konsep aspek kognitif di kelas IV SD N 4 Kalipucang Wetan dari nilai prasiklus, siklus I dan siklus II mengalami peningkatan yang signifikan dan sudah sesuai dengan tingkan keberhasilan yang peneliti buat. Hasil peningkatan pemahaman konsep siswa pada aspek kognitif dapat dilihat pada Tabel 3 dan Gambar 2 sebagai berikut.

Tabel 3 Peningkatan Pemahaman Konsep

\begin{tabular}{cccc}
\multicolumn{4}{c}{ Siswa Aspek Kognitif } \\
\hline Keterangan & $\begin{array}{c}\text { Nilai } \\
\text { Prasiklus }\end{array}$ & $\begin{array}{c}\text { Nilaai } \\
\text { Siklus I }\end{array}$ & $\begin{array}{c}\text { Nilai } \\
\text { Siklus II }\end{array}$ \\
\hline Jumlah & 1537 & 1521 & 1581 \\
Skor Rata-rata & 73,190 & 72,428 & 75,285 \\
Nilai Tertinggi & 88 & 80 & 86 \\
Nilai Terendah & 60 & 40 & 58 \\
Persentase Siswa & $47,61 \%$ & $61,90 \%$ & $76,19 \%$ \\
Tuntas & & & \\
Persentase Siswa & $52,61 \%$ & $38,10 \%$ & $23,81 \%$ \\
Tidak Tuntas & & & \\
\hline
\end{tabular}

\section{Persentase Ketuntasan} Klasikal Pemahaman Konsep Aspek Kognitif

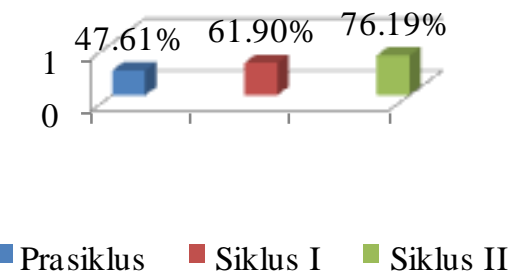

Gambar 2 Diagram Persentase Ketuntasaan Klasikal Pemahaman Konsep Aspek Kognitif
Berdasarkan data di atas diketahui bahwa pemahaman konsep aspek kognitif mengalami peningkatan dari prasiklus dengan persentase ketuntasan klasikal sebesar 47,61\% kemudian pada siklus I meningkat kembali ketuntasan klasikal yaitu sebesar $61,90 \%$. Siklus II meningkat lagi dengan persentase ketuntasan klasikal sebesar 76,19\% . siklus II pemahaman konsep aspek kognitif sudah memenuhi ketuntasan klasikal yaitu $75 \%$.

\section{Pemahaman konsep siswa aspek sikap}

Hasil pemahaman konsep siswa dalam pembelajaran aspek sikap tahun ajaran 2019/2020 pada prasiklus, siklus I dan siklus II mengalami peningkatan yang signifikan dan baik yang dijabarkan dalam bentuk Tabel 4 dan Gambar 3 sebagai berikut

Tabel 4 Peningkatan Pemahaman Konsep Siswa dalam Pembelajaran Aspek sikap

\begin{tabular}{cccccc}
\hline \multirow{2}{*}{ Keterangan } & \multirow{2}{*}{$\begin{array}{c}\text { Pra } \\
\text { siklus }\end{array}$} & \multicolumn{2}{c}{$\begin{array}{c}\text { Siklus I } \\
\text { Pertemuan }\end{array}$} & \multicolumn{2}{c}{$\begin{array}{c}\text { Siklus II } \\
\text { Pertemuan }\end{array}$} \\
\cline { 3 - 6 } & & $\mathbf{1}$ & $\mathbf{2}$ & $\mathbf{1}$ & $\mathbf{2}$ \\
\hline Jumlah Skor & 350 & 600 & 612 & 620 & 628 \\
\hline $\begin{array}{c}\text { Skor Rata- } \\
\text { Rata }\end{array}$ & 40 & 79,3 & 80,9 & 82,0 & $\begin{array}{c}83,0 \\
6\end{array}$ \\
\hline Kriteria & Kurang & Cukup & Baik & Baik & Baik \\
\hline
\end{tabular}

\section{Rata-rata Pemahaman Konsep Aspek Sikap}

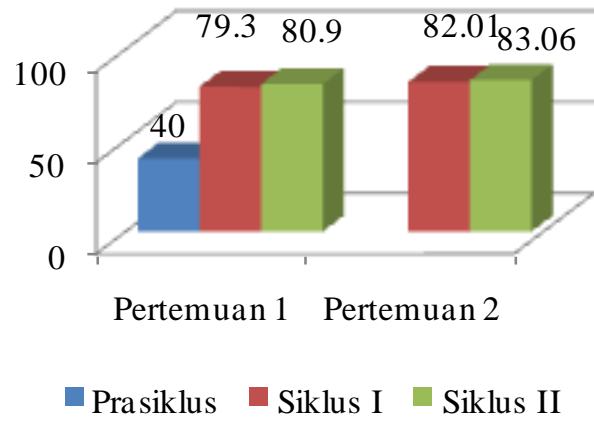

Gambar 3 Diagram Rata-Rata Pemahaaman Konsep Aspek Sikap

Berdasarkan data diatas diketahui bahwa pemahamaan konsep siswa dalam pembelajaran aspek sikap dari prasiklus yaitu dengan skor ratarata 40 kemudian siklus I pertemuan 1 meningkat menjadi skor rata-rata sebesar 73,3. Siklus I pertemuan 2 yaitu mengalami kenaikan lagi dengan skor rata-rata sebesar 80,9. Siklus II pertemuan 1 mengalami kenaikan yaitu sekor 
rata-rata sebesar 82,01 kemudian naik lagi siklus II pertemuaan 2 yaitu skor rata-rata 80,06.

\section{Pemahaman Konsep Siswa Dalam Pembelajaran Aspek Keterampilan}

Hasil pengamatan pemahamaan konsep siswa dalam pembelajaran aspek keterampilan di SD N 4 Kalipucang Wetan tahun ajaran 2019/2020 dari prasiklus, siklus I dan siklus II mengalami peningkatan yang signifikan dan baik yang dijabarkan dalam bentuk Tabel 5 dan Gambar 4 sebagai berikut.

Tabel 5 Peningkatan Pemahaaman Konsep Siswa Dalam Pembelajaran Aspek Keterampilan

\begin{tabular}{cccccc}
\hline \multirow{2}{*}{$\begin{array}{c}\text { Keteran } \\
\text { gan }\end{array}$} & $\begin{array}{c}\text { Pra } \\
\text { siklus }\end{array}$ & \multicolumn{2}{c}{$\begin{array}{c}\text { Siklus I } \\
\text { Pertemuan }\end{array}$} & \multicolumn{2}{c}{$\begin{array}{c}\text { Siklus II } \\
\text { Pertemuan }\end{array}$} \\
\cline { 3 - 6 } & & $\mathbf{1}$ & $\mathbf{2}$ & $\mathbf{1}$ & $\mathbf{2}$ \\
\hline $\begin{array}{c}\text { Jumlah } \\
\text { Skor }\end{array}$ & 360 & 385 & 404 & 410 & 415 \\
\hline $\begin{array}{c}\text { Skor } \\
\text { Rata- } \\
\text { Rata }\end{array}$ & 45 & 76,3 & 80,1 & 80,3 & 82,3 \\
\hline Kriteria & Kurang & Cukup & Baik & Baik & Baik \\
\hline
\end{tabular}

\section{Rata-Rata Pemahaman Konsep Siswa Aspek Keterampilan}

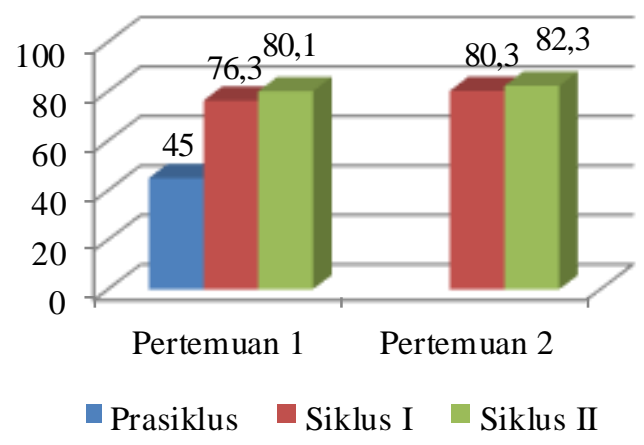

\section{Gambar 4 Diagram Rata-Rata Pemahaman} Konsep Aspek Keterampilan

Berdasarkan data diatas diketahui bahwa pemahaman konsep siswa dalam pembelajaran aspek keterampilan menglami peningkatan yang baik dari parasiklus memperoleh skor rata-rata sebesar 45. Siklus I pertemuan 1 mengalami peningkatan skor rata-rata yaitu 76,3 kemudian siklus I pertemuan 2 mengalami peningkatan kembali yaitu skor rata-rata sebesar 80,1. Siklus II pertemuan 1 mengalami peningkatan lagi yaitu skor rata-rata sebesar 80,3 kemudian siklus II pertemuan 2 yaitu skor rata-rata sebesar 82,3.

\section{PEMBAHASAN}

Hasil penelitian yang telah dilaksanakan menunjukan bahwa terdapat adanya peningkatan kemampuan pemahaman konsep siswa. Hal ini dibuktikan dengan adanya pembelajaran yang sudah berhasil dan telah menunjukkan peningkatan keterampilan mengajar guru. Peningkatan pemahaman konsep dalam pembelajaran pada aspek sikap dan keterampilan serta hasil belajar siswa pada aspek kognitif sudah mencapai indikator keberhasilan yang diharapkan dengan penerapan model pembelajaran Problem Based Learning (PBL) berbantuan media kartu gambar ilustrasi di kelas IV SD N 4 Kalipucang Wetan.

Peningkatan pemahaman konsep siswa dapat dilihat dari hasil evaluasi skor rata-rata prasiklus sebesar 73,190 dengan persentase ketuntasan sebesar $47,61 \%$. Siklus I skor ratarata sebesar 72,428 dengan persentase ketuntasan sebesar 61,90\%. Siklus II mengalami peningkatan kembali yaitu skor rata-rata sebesar 75,285 dengan persentase ketuntasan sebesar $76,19 \%$.

Pemahaman konsep pada aspek sikap prasiklus skor rata-rata yaitu sebesar 40 dengan kriteria kurang. Siklus I pertemuan 1 mengalami peningkatan yaitu skor rata-rata sebesar 79,3 dengan kriteria cukup dan siklus I pertemuan 2 skor rata-rata sebesar 80,9 dengan kriteria baik. Siklus II pertemuan 1 skor rata-rata sebesar 82,01 dengan kriteria baik dan siklus II pertemuan 2 skor rata-rata sebesar 83,06 dengan kriteria baik.

Pemahaman konsep pada aspek keterampilan skor rata-rata prasiklus yaitu sebesar 45 dengan kriteria kurang. Siklus I pertemuan 1 skor rata-rata sebesar 76,3 dengan kriteria cukup dan siklus I pertemuan 2 skor ratarata sebesar 80,1 dengan kriteria baik. Siklus II pertemuan 1 skor rata-rata sebesar 80,3 dengan kriteria baik dan siklus II pertemuan 2 skor ratarata sebesar 82,3 dengan kriteria baik.

Hasil penelitian yang dilakukan senada dengan riset Novellia, dkk (2018); penelitian Setiawan dkk (2013); riset Prihantono, dkk (2014); penelitian Lestari dan Surajhuddin (2014); serta riset Mintarsih dan Termedi (2017). Penelitian Novellia, dkk (2018) menemukan bahwa kemampuan berpikir kritis menunjukkan adanya peningkatan dari prasiklus dengan persentase yaitu sebesar 71,06\% kemudian kembali meningkat pada siklus I yaitu dengan 


\section{Virginia Annisa, Nur Fajrie, dan Muhammad Noor Ahsin \\ PENERAPAN MODEL PROBLEM BASED LEARNING BERBANTUAN MEDIA KARTU .. WASIS: Jurnal Ilmiah Pendidikan Volume 2 Nomor 1, Mei 2021, hlm. 1-8}

persentase sebesar $86,84 \%$. Siklus II mengalami peningkatan kembali yaitu persentase sebesar $89,47 \%$. Hasil belajar siswa pada prasiklus dengan persentase sebesar 55,26\% kemudian meningkat pada siklus I dengan persentase sebesar 78,94\%. Siklus II meningkat kembali yaitu dengan persentase sebesar $86,84 \%$.

Riset Setiawan, dkk (2013) menemukan bahwa peningkatan pemahaman konsep siswa pada prasiklus dengan persentase sebesar $53,33 \%$ kemudian meningkat kembali pada siklus I dengan persentase sebesar $73,33 \%$ menikat lagi pada siklus III dengan persentase sebesar 93,33\%.

Penelitian Prihantono, dkk (2014) menunjukkan bahwa terdapat adanya peningkatan pemahaman konsep siswa yaitu dengan persentase sebesar $28 \%$ kemudian meningkat kembali pada siklus I dengan persentase sebesar $62,96 \%$. Siklus II meningkat lagi dengan persentase sebesar 85,18\% kemudian pada siklus III meningkat kembali yaitu dengan persentase sebesar $92,59 \%$.

Riset Lestari dan Surajhuddin (2014) menunjukkan terdapat adanya peningkatan hasil belajar siswa siklus I memperoleh persentase sebesar 65\%. Siklus II meningkat kembali memperoleh persentase sebesar $72 \%$ kemudian siklus III meningkat dengan persentase sebesar $83 \%$.

Penelitian Mintarsih dan Termedi (2017) menunjukkah bahwa hasil dari pembelajaran Problem Based Learning (PBL) siklus I, II, dan III mengalami peningkatan yang baik. Siklus I skor rata-rata pemehaman konsep materi polotik luar Negeri Indonesia sebesar 7,15 dan sikap cinta tanah air memperoleh skor rata-rata sebesar 84. Siklus II memperoleh skor rata-rata pemahaman konsep politik luar Negeri Indonesia sebesar 7,5 dan sikap cinta tanah air memperoleh skor rata-rata sebesar 85 . Siklus III memperoleh skor rata-rata pemahaman konsep siswa politik luar Negeri Indonesia sebesar 8,3 dan sikap cinta tanah air skor rata-rata sebesar90.

\section{SIMPULAN}

Berdasarkan hasil penelitian dan pembahasan penelitian tindakan kelas maka, dapat disimpulkan bahwa model pembelajaran Problem Based learning berbantuan media kartu gambar ilustrasi dapat meningkatkan pemahaman konsep siswa SD N 4 Kalipucang Wetan Jepara tahun ajaran 2019/2020. Peningkatan keterampilan guru dan pemahaman konsep siswa pada aspek pengetahuan, aspek sikap dan aspek keterampilan.
Terjadi peningkatan keterampilan guru pada siklus I dan siklus II. Siklus I memperoleh persentase sebesar $67 \%$ dalam kriteria baik. Pada siklus II memperoleh persentase sebesar $78 \%$ dalam kriteria baik yang sudah mencapai indikator keberhasilan yang ditetapkan oleh peneliti yaitu $\geq 75 \%$.

Terjadinya peningkatan pemahaman konsep siswa kelas IV SD N 4 Kalipucang Wetan Jepara sesudah menerapkan model pembelajaran problem based learning berbantuan media kartu gambar ilustrasi. Hasil evaluasi skor rata-rata prasiklus sebesar 73,190 dengan persentase ketuntasan sebesar $47,61 \%$.

\section{DAFTAR PUSTKA}

Ardianti, S. D., Wanabuliandari, S., \& Rahardjo, S. (2019). The Implementation Of E-JAS Science Edutainment To Improve Elementary School Student's Conceptual Understanding. Unnes Science Education Journal, 8(1).

Arikunto, S. 2014. Prosedur Penelitian Suatu Pendekatan Praktik. Jakarta: PT Grafindo Persada.

Astuti, N. D., Ahsin, M. N., \& Masfuah, S. 2020. Efektivitas Model Group Investigation Berbantuan Media Watak Kalinyamatan Terhadap Pemahaman Konsep Siswa. WASIS: Jurnal Ilmiah Pendidikan, 1(2), 60-67.

Depdiknas. 2003. Undang-undang RI No.20 tahun 2003. Tentang sistem pendidikan nasional.

Depdiknas, 2006. Permen Nomor 22 Tahun 2006. Jakarta: Depdiknas.

Faiz Amalia, A., Roysa, M., dan Ismaya, E.A. 2020. Penerapan Model Time Token Berbantuan Media Kartu Kuartet Untuk Meningkatkan Hasil Belajar Siswa Sekolah Dasar. NATURALISTIC : Jurnal Kajian Penelitian Pendidikan Dan Pembelajaran, 5 (1): 643-649.

Harja, M. 2012. Pemahaman Konsep Matematis. (Online) http://mediaharja. blogspot.co.id/2012/05/pemahamankonsep-matematis.

Kusumawati, W. 2015. Penerapan Model Problem Based Learning Pada Mata 
Virginia Annisa, Nur Fajrie, dan Muhammad Noor Ahsin

PENERAPAN MODEL PROBLEM BASED LEARNING BERBANTUAN MEDIA KARTU ...

WASIS: Jurnal Ilmiah Pendidikan Volume 2 Nomor 1, Mei 2021, hlm. 1-8

Pelajaran IPS untuk Meningkatkan Hasil Belajar Siswa Kelas VI SDN Semboro 01 Kecamatan Semboro Kabupaten Jember Tahun Ajaran 2014/2015. Pancaran Pendidikan, 4 (4): 1-12.

Lestari, W, D dan Siradjuddin. 2014. Peningkatan Hasil Belajar IPS Melalui Model Pembelajaran Problem Based Learning pada Siswa Kelas V SDN Pojokerto 1 Jombang. Jurnal PGSD FIP Universitas Negeri Surabaya, 2 (3): 1-13

Malinda Z.A., Murtono, dan Zuliana E. 2017. Problem Based Learning Berbantuan Lego Meningkatkan Pemecahan Masalah Siswa Sekolah Dasar. REFLEKSI EDUKATIKA : Jurnal Ilmiah Kependidikan, 8 (1): 66-73.

Mintarsih, M., dan Tarmedi, D. 2018. Penerapan Model Problem Based Learning dalam Meningkatkan Pemahaman Konsep Politik Luar Negeri Indonesia dan Sikap Cinta Tanah Air di Kelas VI SDN Mekarjaya 11 Kota Depok. Jurnal Ilmu Pendidikan (JIP) STKIP Kusuma Negara, 9 (2): 31-40.

Novellia, M. 2018. Penerapan Model Pembelajaran Problem Based Learning (Pbl) Untuk Peningkatan Kemampuan Berpikir Kreatif Dan Hasil Belajar Siswa Dalam Pembelajaran Tematik. Journal For Lesson And Learning Studies, 1 (2): 149-156.

Putri, P. M. 2012. Pemahaman Konsep Matematika Pada Materi Turunan Melalui Pembelajaran Teknik Probing. Jurnal Pendidikan Matematika, 1 (1).

Tri Rahmanto, Lufti. 2018. Penerapan Model Problem Based Learning Untuk Meningkatkan Kemampuan Berpikir Kritis Pada Muatan IPS Dalam Tema Indahnya Keragaman Di Negeriku Kelas IV SDN Singogalih Sidoarjo. Jurnal Penelitian Pendidikan Guru Sekolah Dasar, 6 (11).

Santoso, S., dan Oktavianti, Ika. 2015. Peningkatan Hasil Belajar PKN Siswa Kelas VI SD 3 Jekulo Kudus Melalui Model Problem Based Learning.
REFLEKSI EDUKATIKA : Jurnal Ilmiah Kependidikan, 5 (1).

Setiawan, A., Soegiyanto, H., dan Lestari, L. Penggunaan Model Pembelajaran Problem Based Learning Untuk Meningkatkan Pemahaman Konsep Masalah-Masalah Sosial. Jurnal FKIP UNS, 2 (4): 1-6.

Sulistyani., S. 2020. Upaya Meningkatkan Keterampilan Menulis Huruf Jawa Melalui Diskusi Kelompok Berbantu Kartu Huruf Pada Peserta Didik Kelas VI SD 1 Prambatan Kidul Kudus. REFLEKSI EDUKATIKA : Jurnal Ilmiah Kependidikan, 10 (2): 239-250.

Susanti, P. D. A. 2018. Peningkatan Hasil Belajar IPA Melalui Penerapan Model Pembelajaran Berbasis Masalah (Problem Based Learning) Pada Siswa Kelas V SDN Purwasari III Kabupaten Karawang. In Prosiding Seminar Dan Diskusi Pendidikan Dasar.

Zuliana, Eka. 2015. Pengaruh Model Problem Based Learning Berbantuan Kartu Masalah Terhadap Kemampuan Pemecahan Masalah Matematika Siswa Sekolah Dasar. REFLEKSI EDUKATIKA : Jurnal Ilmiah Kependidikan, 5 (1). 